\title{
Constraints in the Use of Social Media as Perceived by Researchers and Extension Personnel in Karnal District of Haryana, India
}

\author{
N.P. Darshan ${ }^{1 *}$ and B.S. Meena ${ }^{2}$ \\ ${ }^{1}$ Agricultural Extension Division, PJTSAU, Hyderabad-500030, Telangana, India \\ ${ }^{2}$ Dairy Extension Division, National Dairy Research Institute, Karnal-132001, Haryana, India \\ *Corresponding author
}

\section{A B S T R A C T}

\begin{tabular}{|c|}
\hline Keywords \\
\hline $\begin{array}{l}\text { Researchers and } \\
\text { extension } \\
\text { personnel, Social } \\
\text { media, Agriculture, } \\
\text { Constraints, Karnal. }\end{array}$ \\
\hline Article Info \\
\hline $\begin{array}{l}\text { Accepted: } \\
\text { 26 September } 2017 \\
\text { Available Online: } \\
10 \text { October } 2017\end{array}$ \\
\hline
\end{tabular}

Keywords

Researchers and extension media, Agriculture, Constraints, Karnal

\section{Introduction}

Information is critical in agricultural development because it is a tool for communication between stakeholders and serves as a channel for assessing trends and shaping decisions (Kalusopa, 2005). Farming requires information and technical expertise hence the need for extension services however, due to various factors extension services are not readily available to all researchers and extension personnel. A consensus exists that extension services, if functioning effectively, improve agricultural productivity by providing researchers and extension personnel with information that helps them to optimize their use of limited resources (Muyanga and Jayne, 2006).
Globalization and technological change processes that have accelerated in tandem over the past years have created a new global economy powered by technology, fueled by information and driven by knowledge. Agriculture sector is also witnessing radical changes and challenges at national and global level. The slow growth observed in the agriculture sector is causing concerns for the future food and nutritional security of the country. The number of clients who need to be covered by extension services is large, and the cost of reaching them is high. Adding to this challenge, researchers and extension personnel' information needs vary even within a given geographical area because of 
variations in soil, elevation, microclimate, and researchers and extension personnel' means enterprises and capabilities.

The goals of agricultural extension includes transferring information from the global knowledge base and from local research to researchers and extension personnel, enabling them to clarify their own goals and possibilities, educating them on how to make better decisions, and stimulating desirable agricultural development (Van den Ban and Hawkins, 1996). Investments in extension services have the potential to improve agricultural productivity and increase researchers and extension personnel incomes especially in developing economies where more than 90.00 per cent of the world's (nearly 1 million) extension personnel are present. Yet the impact of extension on farm performance is varied, reflecting differences in how extension services are delivered and in the circumstances of service recipients.

Estimates indicated that 60.00 per cent of farmers do not access any source of information for advanced agricultural technologies resulting in huge adoption gap (NSSO, 2005). In India, there are about 120 million farm holdings and the number is growing year by year. At least to provide one village extension personnel for 800-1000 farm families, the requirement of field level extension personnel is estimated to be about 1300000-1500000, against which the present availability is only about 100000 personnel (PC, GOI, 2007).

The emerging challenges and opportunities call for a paradigm shift in the innovation driven agricultural research system to connect inventions with all the stakeholders in the entire food supply chain. Social media and internet are embracing almost all the sectors of life. In agriculture there is a need to reach each and every farmer and provide them the updated information. Communities of social media are open networks where everyone (i.e. clients, users, members) has an opportunity to contribute their ideas and to support mass innovation with one-to-one, one-to-many, and many-to-many interactions (Ashley et al., 2009).

Despite the increasing penetration and influence of social media, researchers and extension personnel abstain from using it due to various constraints. So keeping these points in mind the study was mainly focused to reveal the constraints as perceived with respect to the use of social media by the researchers and extension personnel of Karnal district.

\section{Materials and Methods}

\section{Description of Study Area}

The study was conducted in Karnal district of Haryana. Karnal, 'the city of Daanvir Karan' was formed as a District on November1, 1966. It is $123 \mathrm{~km}$ from Delhi on the National Highway NH1, (called the GT Road), and 126 $\mathrm{km}$ from Chandigarh. It lies between 29 09'50" and 29 50' North latitude and 76 31' $15^{\prime \prime}$ and 77 12'45" East longitude, its height from sea level is around 240 meters. The district was purposively selected as it has contributed extensively to the green revolution and the socio economic status and literacy level of the respondents was good.

\section{Sampling Technique}

Since the distribution of the social media users in the district is unknown whosoever come in contact with ICAR and other agricultural institutes/ departments were selected (most of the contacts were gathered from the institutes). The list of names was gathered from KVKs, ICAR institutes located in Karnal and sampled randomly. A total of 
40 researchers and 40 extension personnel each were selected randomly constituted sample size. A structured, pre-tested semistructured interview schedule was developed for collecting data from the respondents according to the objective of the study. Data were collected from the respondents by conducting personal interview method. Statistical tools like frequency, percentage and weighted mean score were used for analysis of the data.

\section{Results and Discussion}

Constraints perceived by the researchers in disseminating information through social media

With respect to the constraints perceived by the researchers, it was observed from the Table-1 that weak research-extension linkage (14.83) was the foremost constraint in using the social media as they felt that there was limited scope and platform for integration of information/technology through interaction between researchers and extension personnel. Next constraint was unsuitable and incomprehensible information (14.50) as many felt that suitable, need based, timely, site specific, understandable information were not adequately generated by the researchers and extension personnel.

It was also evident that many researchers perceived the constraints like inadequate timely responses (14.33) as there was asynchronous interaction and lack of reciprocal interaction discouraged them from using media tools, time constraints (13.16), difficulty to find relevant information due to large number of sources (12.16), inadequate technical knowledge/skill (11.33) on the part of farmers and majority of researchers were not trained on how to use particular tool, and preference to traditional dissemination methods (10.16) (Darshan, 2015).

Table.1 Constraints perceived by the researchers in disseminating Information through social media $(n=40)$

\begin{tabular}{|l|c|c|c|c|}
\hline \multicolumn{1}{|c|}{ Category } & $\begin{array}{c}\text { Most } \\
\text { serious }\end{array}$ & Serious & $\begin{array}{c}\text { Least } \\
\text { serious }\end{array}$ & WMS \\
\hline Weak research extension linkage & $15(37.50)$ & $19(47.50)$ & $\begin{array}{c}6 \\
(15.00)\end{array}$ & 14.83 \\
\hline $\begin{array}{l}\text { Unsuitable and incomprehensible } \\
\text { information }\end{array}$ & $13(32.50)$ & $21(52.50)$ & $\begin{array}{c}6 \\
(15.00)\end{array}$ & 14.50 \\
\hline Lack of response & $15(37.50)$ & $16(40.00)$ & $\begin{array}{c}9 \\
(22.50)\end{array}$ & 14.33 \\
\hline Time constraint & $12(30.00)$ & $15(37.50)$ & $13(32.50)$ & 13.16 \\
\hline $\begin{array}{l}\text { Difficulty to find relevant information } \\
\text { (due to large number of sources) }\end{array}$ & $9(22.50)$ & $15(37.50)$ & $16(40.00)$ & 12.16 \\
\hline $\begin{array}{l}\text { Inadequate technical knowledge/ skill } \\
(7.50)\end{array}$ & $22(55.00)$ & $15(37.50)$ & 11.33 \\
\hline $\begin{array}{l}\text { Preference to traditional dissemination } \\
\text { methods }\end{array}$ & $\begin{array}{c}2 \\
(5.00)\end{array}$ & $17(42.50)$ & $21(52.50)$ & 10.16 \\
\hline
\end{tabular}

Figures in the parenthesis indicate per cent, WMS- weighted mean score 
Table.2 Constraints perceived by the extension personnel in disseminating Information through social media $(n=40)$

\begin{tabular}{|c|c|c|c|c|}
\hline Category & Most serious & Serious & $\begin{array}{c}\text { Least } \\
\text { serious }\end{array}$ & WMS \\
\hline $\begin{array}{l}\text { Unsuitable and incomprehensible } \\
\text { information }\end{array}$ & $\begin{array}{c}15 \\
(37.50)\end{array}$ & $\begin{array}{c}17 \\
(42.50)\end{array}$ & $\begin{array}{c}8 \\
(20.00)\end{array}$ & 14.50 \\
\hline Inadequate service & $\begin{array}{c}11 \\
(27.50) \\
\end{array}$ & $\begin{array}{c}21 \\
(52.50)\end{array}$ & $\begin{array}{c}8 \\
(20.00)\end{array}$ & 13.83 \\
\hline Lack of response & $\begin{array}{c}9 \\
(22.50)\end{array}$ & $\begin{array}{c}24 \\
(60.00)\end{array}$ & $\begin{array}{c}7 \\
(17.50)\end{array}$ & 13.66 \\
\hline Time constraint & $\begin{array}{c}12 \\
(30.00)\end{array}$ & $\begin{array}{c}16 \\
(40.00)\end{array}$ & $12(30.00)$ & 13.33 \\
\hline $\begin{array}{l}\text { Inadequate technical knowledge/ } \\
\text { skill }\end{array}$ & $\begin{array}{c}10 \\
(25.00)\end{array}$ & $\begin{array}{c}13 \\
(32.50)\end{array}$ & $17(42.50)$ & 12.16 \\
\hline $\begin{array}{l}\text { Difficulty to find relevant } \\
\text { information (due to large number } \\
\text { of sources) }\end{array}$ & $\begin{array}{c}4 \\
(10.00)\end{array}$ & $\begin{array}{c}22 \\
(55.00)\end{array}$ & $14(35.00)$ & 11.66 \\
\hline $\begin{array}{l}\text { Preference to traditional } \\
\text { dissemination methods }\end{array}$ & $\begin{array}{c}2 \\
(5.00)\end{array}$ & $\begin{array}{c}20 \\
(50.00)\end{array}$ & $18(45.00)$ & 10.66 \\
\hline
\end{tabular}

Figures in the parenthesis indicate per cent, WMS- weighted mean score

Constraints perceived by the extension personnel in disseminating information through social media

With respect to the constraints perceived by the extension personnel, it was observed from the Table-2 that unsuitable and incomprehensible information (14.50) was the foremost constraint in using the social media. Many felt that suitable, need based, timely, site specific, understandable information were not adequately generated by the researchers and extension personnel.

It was also evident that many extension personnel had perceived the constraints like inadequate service of network, speed of the service etc. (13.83), inadequate timely responses (13.66), time constraints (13.33), inadequate technical knowledge/ skill (12.16) as the majority of extension personnel were not trained on how to use particular tool, difficulty to find relevant information due to large number of sources (11.66), and orientation to traditional dissemination methods (10.66) in using social media (Darshan, 2015).

A critical analysis of constraints as perceived by researchers and extension personnel in using social media revealed that majority of researchers and extension personnel felt improper service of network provider, difficulty to find relevant information, inadequate skill in using tools, unsuitable and incomprehensible information etc. were the constraints. In the light of farmers moving away from agriculture there is a need to attract and retain them in agriculture sector. In this context social media forms good media tools and there is a need to address the issues with respect to the use of social media. There is also a great need to establish secure platform to encourage research-extensionfarmer interaction. It is an important obligation on the part of research-extension system (both public and private) to collaborate services of Telecom regulatory 
authority of India (TRAI) and ICT service providers to continue giving support mechanisms to social media users.

\section{References}

Ashley, H., Corbett, J., Jones, D., Garside, B. and Rambaldi, G. 2009. Change at Hand: Web 2.0 for Development. Participatory Learning and Action, 59: 8-20.

Darshan N. P., 2015. Exploring the potential use of social media in communicating agricultural information in Haryana. M. Sc. Thesis. National Dairy Research Institute. Karnal (India).

Kalusopa, T., 2005. The Challenges of Utilising Information and Communication Technologies (ICT's) for the small scale farmer in Zambian. IN: Library Tech, 23(3)414-424, www.emeraldinsight.com/0737-

8831.htm. Retrieved on 8th January, 2011.
Muyanga, M., and Jayne, T. S. 2006. Agricultural Extension in Kenya: Practice Policy and Lessons. Practice and Policy Lessons. Tegemeo Institute of Agriculture and Policy Development, Egerton University.

NSSO, 2005. Access to modern technology for farming, situation assessment survey of farmers, 59th Round, Report No. 499, National Sample Survey Organization (NSSO), Ministry of Statistics and Program Implementation, Government of India, New Delhi.

PC, GoI, 2007. Recommendations of working group on agricultural extension for formulation of eleventh five year plan (2007-12), Planning Commission, Government of India, New Delhi. http://planning commission.nic.in/plans/planrel/11thf.ht $\mathrm{m}$

Van Den Ban, A. W., and H. S. Hawkins 1996. Agricultural extension. Oxford [etc.], Blackwell.

\section{How to cite this article:}

Darshan, N.P. and Meena, B.S. 2017. Constraints in the Use of Social Media as Perceived by Researchers and Extension Personnel in Karnal District of Haryana, India. Int.J.Curr.Microbiol.App.Sci. 6(10): 3239-3243. doi: https://doi.org/10.20546/ijcmas.2017.610.379 